\title{
Efektivitas Pelatihan Pemberian Dukungan Sosial pada Walinapi dengan Metode Bermain dan Permainan Peran
}

\author{
Alimatus Sahrah ${ }^{1} \mathcal{E}$ Reny Yuniasanti ${ }^{2}$ \\ 1,2Fakultas Psikologi Universitas Mercu Buana Yogyakarta
}

\begin{abstract}
The skills of prisoner coaching to provide social support by walinapi in every penitentiary need to be improved. This experimental study aims to determine the effectiveness of social support training using the Game method and the Role Play method in improving the ability to make Social Support welfare against prisoners in the Penitentiary of Yogyakarta. The research subject was 20 prisoners guardian, consisting of 9 men and 11 women. Social Support Training with Game and Role Playing Methods is a treatment to enhance the welfare social support capabilities of prisoners. Training Effectiveness is measured by evaluation of reactions, evaluation of learning and behavioural evaluation. Measurement of social support capabilities is done before and after training using a scale based on 5 aspects of social support. The research data analysis uses independent $t$-test and pair comparison $t$-test techniques. The results of the study show that, (1) social support training is effectively improving the ability to support social welfare of the prisoners; (2) there is no difference in effectiveness between social support training using the game method and the role play method.
\end{abstract}

Keywords: game methods; role play methods; social support training

Abstrak. Keterampilan pembinaan narapidana untuk memberikan dukungan sosial oleh walinapi di setiap Lembaga Pemasyarakatan perlu ditingkatkan. Penelitian ini bertujuan untuk mengetahui efektivitas pelatihan dukungan sosial dengan menggunakan metode Bermain dan metode Permainan Peran dalam meningkatkan kemampuan melakukan Dukungan Sosial walinapi terhadap para narapidana di Lembaga Pemasyarakatan Yogyakarta. Subjek penelitian adalah 20 orang walinapi, yang terdiri dari 9 orang pria dan 11 orang wanita. Pelatihan Dukungan Sosial dengan metode Bermain dan Permaian Peran merupakan perlakuan untuk meningkatkan kemampuan dukungan sosial walinapi terhadap para narapidana. Efektivitas pelatihan diukur dengan evaluasi reaksi, evaluasi pembelajaran dan evaluasi perilaku. Pengukuran kemampuan dukungan sosial dilakukan sebelum dan sesudah pelatihan menggunakan skala yang berdasarkan lima aspek dukungan sosial. Analisis data penelitian menggunakan teknik independent $t$-test dan pair comparison $t$-test. Hasil penelitian menunjukkan bahwa, (1) pelatihan dukungan sosial adalah efektif meningkatkan kemampuan melakukan dukungan sosial walinapi terhadap narapidana; (2) tidak ada perbedaan efektivitas antara pelatihan dukungan sosial yang menggunakan metode Bermain dan metode Permainan Peran.

Kata kunci: metode bermain; metode permaian peran; pelatihan dukungan sosial

Upaya Lembaga Pemasyarakatan (Lapas) dalam melakukan pembinaan terhadap Warga Binaan Lapas (narapidana), sangat tergantung kepada kemampuan dari para pembimbing narapidana yang disebut sebagai Walinapi. Tugas Walinapi adalah

\footnotetext{
${ }^{1}$ Korespondensi mengenai artikel ini dapat melalui: sahrah@mercubuana-yogya.ac.id
} 
membimbing narapidana agar menyadari kesalahan, memperbaiki diri, dan tidak mengulangi tindak pidana yang pernah dilakukannya. Dari penelitian yang dilakukan oleh Sahrah, Lailatushifah, Indiyah, Susilaningsih, dan Astuti, (2014) ditemukan bahwa selain faktor kebermaknaan hidup dan faktor kepercayaan diri, faktor dukungan sosial yang dilakukan Walinapi sangatlah berpengaruh terhadap peningkatan kesejahteraan subjektif para narapidananya. Hanya saja dari penelitian Sahrah, Yuniasanti dan Indiyah (2015) didapatkan bahwa kemampuan melakukan Dukungan Sosial (selanjutnya disingkat DS) para walinapi masih kurang memadai. Oleh sebab itu, maka perlu adanya usaha untuk meningkatkan kemampuan melakukan DS pada Walinapi tersebut.

Dukungan Sosial menurut Johnson \& Johnson (2013) diartikan sebagai suatu pertukaran dari berbagai sumber dengan maksud meningkatkan kesejahteraan, dan hal ini dapat terjadi jika ada keberadaan orang lain yang dapat diandalkan untuk dimintai bantuan, dorongan, penerimaan dan perhatian di saat mengalami kesusahan. Hupcey (1998) menyatakan bahwa DS menunjuk pada beberapa jenis interaksi positif atau perilaku bermanfaat yang diberikan kepada orang yang membutuhkan dukungan.

Istilah DS secara umum digunakan untuk mengacu pada penerimaan rasa aman, peduli, penghargaan atau bantuan yang diterima seseorang dari orang lain atau kelompok. Sarafino \& Smith, (2014) menyatakan bahwa "Social support is generally used to refer to the perceived comfort, caring, esteem or help a person receives from other people or groups". Selanjutnya kedua penulis tersebut membedakan lima jenis DS, yaitu: (1) dukungan emosional. Pada aspek ini mencakup ungkapan kepedulian, empati, dan perhatian terhadap orang yang bersangkutan. Dukungan emosional ini terindikasi dengan penyediaan rasa nyaman, ketentraman hati, dan perasaan dicintai bagi seseorang yang mendapatkannya. (2) Dukungan penghargaan. Aspek ini terjadi lewat ungkapan penghargaan positif untuk individu bersangkutan, dorongan maju, atau persetujuan dengan gagasan atau perasaan individu dan perbandingan positif individu dengan orang-orang lain. (3) Dukungan instrumental. Aspek ini mencakup bantuan langsung yang dapat berupa jasa, uang, dan waktu. (4) Dukungan informatif. Aspek ini mencakup memberi nasihat, petunjuk-petunjuk, saran-saran, informasi, dan umpan balik. (5) Dukungan jaringan sosial. Aspek ini mencakup perasaan keanggotaan dalam kelompok. Dukungan jaringan sosial merupakan perasaan keanggotaan dalam suatu kelompok, saling berbagi kesenangan dan aktivitas sosial.

Metode pelatihan dianggap merupakan pilihan untuk dapat meningkatkan kemampuan Walinapi dalam memberikan DS. Metode pelatihan merupakan metode yang cukup efektif untuk meningkatkan motivasi, mengubah struktur kognitif, memodifikasi sikap, dan menambah keterampilan berperilaku (Robbins, 2008). Pareek, Rao, \& Khandelwal (2016) mengatakan bahwa pelatihan dapat memberikan suatu kesempatan untuk melatih keterampilannya. Hal ini sejalan dengan pendapat (Mathis, Jackson, Valentine, \& Meglich, 2015), yang mengatakan bahwa pelatihan adalah suatu proses di mana orang-orang dapat mencapai kemampuan tertentu untuk membantu pencapaian tujuan organisasinya. Kunche, Puli, Guniganti, \& Pradesh (2011) juga berpendapat bahwa pelatihan dapat dinyatakan sebagai metode yang diberikan kepada karyawan dalam memenuhi tujuan organisasi. 
Pelatihan sebagai perlakuan untuk modifikasi perilaku yang direncanakan dan sistematis melalui kegiatan pembelajaran untuk menghasilkan peserta mencapai tingkat pengetahuan, keterampilan, kompetensi dan kemampuan untuk melaksanakan pekerjaan mereka secara efektif (Betcherman, 1998). Cole (2002) menegaskan bahwa tujuan utama pelatihan adalah untuk memperoleh dan meningkatkan pengetahuan, keterampilan dan sikap terhadap tugas terkait pekerjaan.

Pelatihan Dukungan Sosial Walinapi, diartikan sebagai suatu program kegiatan pembelajaran yang terencana secara sistematis agar supaya peserta mencapai tingkat pengetahuan, keterampilan, kompetensi dan kemampuan untuk melaksanakan Dukungan Sosial secara efektif kepada para narapidana.

Pilihan metode pelatihan DS yang digunakan adalah dengan metode Bermain dan metode Permainan Peran, yang keduanya menurut Raheja (2015) merupakan pelatihan simulasi pada metode off-the-job. Simulasi dalam hal ini diartikan sebagai lingkungan buatan yang persis sama dengan situasi aktual. Pelatihan dengan metode Bermain, adalah pelatihan yang dirancang dengan baik untuk membantu melatih kebiasaan berfikir, kemampuan analitik, logis dan penalaran, pentingnya kerja tim, manajemen waktu, untuk membuat keputusan yang tidak memiliki informasi lengkap, kemampuan komunikasi dan kepemimpinan. Penggunaan permainan dapat mendorong mekanisme baru yang inovatif untuk mengatasi stres. Menurut JohnsonLaired \& Johnson-Laird (1999) permainan merupakan hasil dari simulasi yang dibuat lebih kompetitif di mana setiap peserta ditantang untuk melihat siapa yang membuat keputusan yang paling efektif. Simulasi permainan dapat meningkatkan energi dan komitmen peserta sehingga meningkatkan motivasi belajar. Selain itu, menurut Keys \& Wolfe (dalam Riggio, 2015) games termasuk metode yang efektif dalam pelatihan. Permainan ini dirancang dapat dilakukan di luar ruangan maupun di dalam ruangan. Raheja (2015) berpendapat bahwa pada pelatihan dengan metode Permainan Peran, setiap peserta pelatihan mengambil peran seseorang yang terkena dampak suatu masalah dan mempelajari dampak dari masalah pada kehidupan manusia dan/atau dampak aktivitas manusia terhadap dunia di lingkungan sekitar dari sudut pandang orang tersebut.

Dalam penelitian ini pelatihan Dukungan Sosial Walinapi dievaluasi dengan menggunakan tiga kriteria pertama dari empat kriteria ukuran keefektifan pelatihan yang sesuai dengan pendapat Kirkpatrick \& Kirkpatrick (2016) yaitu: (1) reaksi; (2) proses belajar.; (3) perubahan perilaku; (4) Hasil. Hasil merupakan ukuran efektivitas pelatihan yang dilihat dari pencapaian tujuan organisasi karyawan, kualitas kerja, efesiensi waktu, jumlah out-put dan penurunan pemborosan. Analisis keefektifan kriteria Hasil belum dilaksanakan mengingat keterbatasan waktu yang diberikan saat penelitian. Hipotesis yang diajukan dalam penelitian ini adalah bahwa Pelatihan Dukungan Sosial efektif untuk meningkatkan kemampuan melakukan dukungan sosial Walinapi.

\section{Metode}

Subjek penelitian ini berjumlah 20 orang Walinapi, yang terdiri dari 9 orang pria dan 11 orang wanita. Karakteristik subjek penelitian adalah: (1) Walinapi yang sedang aktif membimbing narapidana di LAPAS Klas IIA Yogyakarta; (2) memiliki 
Masa kerja minimum 1 tahun; (3) Pendidikan minimum SLA, dan (4) berumur antara 25 tahun sampai dengan 55 tahun. Subjek penelitian ini dibagi secara random menjadi 2 kelompok, yaitu 10 orang pada kelompok perlakuan Pelatihan DS dengan metode Bermain dan 10 orang lainnya pada kelompok yang memperoleh perlakukan Pelatihan DS dengan metode Permainan Peran. Pengelompokan subjek dilakukan secara random.

Penelitian ini menggunakan pendekatan eksperimen dengan desain one group pretest posttest desain, (Sugiyono, 2010). Desain eksperimen dapat dilihat pada Tabel 1.

Tabel 1

Rancangan desain eksperimen

\begin{tabular}{cccc}
\hline $\begin{array}{c}\text { Kelompok } \\
\text { Subjek }\end{array}$ & PreTest & Perlakuan & PostTest \\
\hline 1 & O1 & X1 & O2 \\
2 & O3 & X2 & O4 \\
\hline
\end{tabular}

Keterangan:

O1 : Pretest kelompok 1; O2: Posttest kelompok 1; O3: Pretest kelompok 2; O4: Posttest kelompok 2;

X1 : Pelatihan DS dengan metode Bermain; X2: Pelatihan DS dengan metode Permainan Peran

Penelitian dilaksanakan dalam tiga tahapan. Pada tahap pra-eksperimen, dilakukan pengumpulan data menggunakan metode Skala Dukungan Sosial (DS). Skala ini telah diuji-cobakan dan ditemukan bahwa besaran koefisien korelasi aitem dengan aitem total yang telah dikoreksi berkisar antara 0.275 s.d. 0.713, dan koefisien Reliabilitas Alpha Cronbach sebesar 0,959. Karena instrumen ini dipergunakan pada saat pretest dan posttest, maka pengalaman mengerjakan pretest ditengarai akan memengaruhi hasil posttest. Sebagai upaya untuk menghindari ancaman tersebut, maka dilakukan pengacakan nomor aitem saat melakukan post-test, seperti yang disarankan oleh Cook (2014).

Penyusunan modul pelatihan DS dengan metode Bermain dan dengan metode Permainan Peran, menggunakan acuan lima aspek DS yang dikemukakan oleh Sarafino \& Smith (2014), yaitu dukungan emosional, dukungan penghargaan, dukungan instrumen, dukungan informatif dan dukungan jaringan sosial. Aspek-aspek DS tersebut kemudian dijabarkan menjadi sesi-sesi pada pelatihan yang mengacu pada pelatihan Khaerani, Palila, Islam, Sunan, \& Yogyakarta (2014), yaitu Sesi 1, Dukungan Emosional, yang meliputi materi untuk ketrampilan melakukan (a) empati, ikut merasakan apa yang dirasakan orang lain, (b) peduli pada diri sendiri dan orang lain, dan (c) penghargaan pada diri sendiri dan orang lain; Sesi 2. Dukungan Penghargaan, yang terdiri dari ketrampilan untuk melakukan (a) ungkapan positif, (b) dorongan untuk maju, dan (c) penguatan positif (gagasan dan perasaan individu) dan penghargaan; sesi 3, dukungan informasi, yang terdiri dari ketrampilan untuk (a) memberikan petunjuk dan saran, dan (b) memberikan umpan balik; Sesi 4. Dukungan instrumental, yang merupakan ketrampilan untuk (a) membantu dengan hal-hal yang nyata, dan (b) memberi hal yang baik dan berguna.

Pada pelaksanaan pelatihan terdiri dari tiga tahapan pelaksanaan pelatihan juga, yaitu tahap perkenalan, tahap inti dan tahap akhir. Pada tahap perkenalan ini meliputi kegiatan pengisian lembar pelaporan diri dan ice breaking. Pada tahap inti inilah yang membedakan kelompok pertama subjek penelitian dan kelompok dua subjek penelitian, di mana pada kelompok pertama subjek penelitian 
mendapatkan materi pelatihan DS dengan metode Bermain dan kelompok kedua subjek penelitian mendapat materi DS dengan metode Permainan Peran. Pemberian pengalaman subjek dalam melakukan kegiatan bermain permainan (games) maupun kegiatan bermain peran (role play), bertujuan untuk memberi pemahaman kepada para peserta secara langsung agar dapat menimbulkan pengalaman intelektual, pengalaman emosional dan pengalaman yang bersifat fisikal (Ancok, 2002). Tahap akhir pelatihan ini meliputi penyimpulan pelatihan dan evaluasi. Di tahap akhir ini, beberapa peserta dapat mengeluarkan emosi dan perasaan. Peserta dapat mengungkapkan apa yang diperoleh dari pelatihan hari ini untuk dapat diterapkan dikehidupan kerjanya.

Tahap pasca eksperimen berupa pemberian posttest pada setiap kelompok subjek penelitian yang diberi perlakuan pelatihan DS menggunakan metode Bermain maupun kelompok yang diberi perlakuan dengan metode Permainan Peran. Karena menurut Cook dan Campbell (dalam Alkin, 2012) panjangnya tenggang waktu antara pretest dan posttest dapat memengaruhi validitas internal penelitian eksperimen, yaitu adanya ancaman tersebut berupa perkembangan kematangan subjek dikarenakan bertambahnya pengalaman individu, maka ditetapkan postest dilakukan setelah dua minggu dari pelaksanaan perlakuan diberikan. Pelatihan DS dalam penelitian ini hanya menggunakan tiga ukuran kriteria yang dikemukakan oleh (Kirkpatrick \& Kirkpatrick, 2016) yaitu evaluasi reaksi, proses belajar, perubahan perilaku saja. Dalam penelitian ini tidak dilakukan evaluasi hasil. Analisis data statistik untuk menguji hipotesis adalah teknik statistik komparasi $t$-test independent dan $t$-test pair comparison.

\section{Hasil}

Subjek penelitian walinapi yang mengikuti penelitian ini adalah sebanyak 20 orang yang terdiri dari 9 orang (45\%) pria dan 11 orang $(55 \%)$ adalah wanita. Umur rata-rata subjek penelitian adalah 42 tahun, dan jika dilihat dari tingkat pendidikan terakhir yang dimiliki oleh walinapi, dapat disimpulkan bahwa sebagian besar walinapi memiliki pendidikan Sarjana (70\%), sedang tingkat pendidikan lainnya adalah SLA, D3 dan S2, yang banyaknya secara berturutturut $5 \%, 10 \%$ dan $15 \%$. Berikut adalah evaluasi hasil pelatihan: evaluasi reaksi, evaluasi pengetahuan (proses belajar) dan perubahan perilaku.

Dari evaluasi reaksi terhadap pelatihan disimpulkan bahwa secara keseluruhan subjek penelitian baik yang mengikuti pelatihan DS dengan metode Bermain, maupun dengan metode Permainan Peran, semua menganggap penyelenggaraan pelatihan adalah memuaskan, yaitu dengan rerata penilaian 3,78. Disimpulkan juga pada kedua kelompok subjek yang mendapat pelatihan DS dengan metode Bermain dan metode Permainan Peran, tidak ada perbedaan penilaiannya terhadap lima aspek penilaian evaluasi reaksi.

Dalam hal ini evaluasi reaksi yang diberikan oleh subjek penelitian mencakup tentang menarik tidaknya pelatihan ini, fasilitatornya, ruangan tempat penyelenggaraan pelatihan, alat peraga yang dipergunakan pada pelatihan, dan kepuasan secara menyeluruh pada pelatihan yang diselenggarakan. Hanya evaluasi reaksi terhadap banyaknya informasi yang didapat, menurut subjek dari kelompok pelatihan dengan metode Permainan Peran (rerata 4,70) yang dapat disimpulkan secara signifikan $(p<0,01)$ lebih tinggi daripada evaluasi reaksi subjek dari kelompok 
pelatihan dengan metode Bermain (rerata $3,20)$ yang dapat dilihat Tabel 1.

Pada penilaian evaluasi pengetahuan atau proses belajar, disimpulkan bahwa pengetahuan dari seluruh subjek penelitian setelah (post-test) mendapatkan pelatihan DS (rerata 44,85) lebih tinggi secara signifikan $(p<0,01)$ daripada pengetahuan dari seluruh subjek penelitian sebelum (pretest) mendapatkan pelatihan DS. Hal yang sama juga disimpulkan pada kelompok subjek yang mendapatkan pelatihan dengan metode Bermain dan kelompok subjek yang mendapatkan pelatihan dengan metode Permainan Peran (lihat Tabel 2).

Tabel 1

Evaluasi reaksi pelatihan dukungan sosial

\begin{tabular}{|c|c|c|c|c|c|c|}
\hline Aspek & Komparasi & $\mathrm{N}$ & Mean & $\mathrm{T}$ & $\mathrm{df}$ & Sig. (2-tailed) \\
\hline \multirow[t]{2}{*}{ Menarik } & M. Bermain & 10 & 3,20 & $-1,134$ & 18 & ,272 \\
\hline & M.P.Peran & 10 & 3,80 & & & \\
\hline \multirow[t]{2}{*}{ B_inform } & M. Bermain & 10 & 3,20 & $-2,807$ & 18 & ,012 \\
\hline & M.P.Peran & 10 & 4,70 & & & \\
\hline \multirow[t]{2}{*}{ Fasilitator } & M. Bermain & 10 & 3,90 & ,000 & 18 & 1,000 \\
\hline & M.P.Peran & 10 & 3,90 & & & \\
\hline \multirow[t]{2}{*}{ Tempat } & M. Bermain & 10 & 4,00 & 1,964 & 18 & ,065 \\
\hline & M.P.Peran & 10 & 3,40 & & & \\
\hline \multirow[t]{2}{*}{ Peraga } & M. Bermain & 10 & 3,90 & 1,897 & 18 & 074 \\
\hline & M.P.Peran & 10 & 3,30 & & & \\
\hline \multirow[t]{2}{*}{ Kepuasan } & M. Bermain & 10 & 4,00 &,- 557 & 18 & ,584 \\
\hline & M.P.Peran & 10 & 4,10 & & & \\
\hline \multirow[t]{2}{*}{ Total E_Reaksi } & M. Bermain & 10 & 22,20 & $-1,124$ & 18 & ,276 \\
\hline & M.P.Peran & 10 & 23,20 & & & \\
\hline
\end{tabular}

Tabel 2

Evaluasi pengetahuan pelatihan dukungan sosial

\begin{tabular}{|c|c|c|c|c|c|c|c|}
\hline & Komparasi & t-test & $\mathrm{N}$ & Mean & $t$ & $\mathrm{df}$ & Sig. (2-tailed) \\
\hline \multirow[t]{2}{*}{ M.Bermain } & Pre & Pair-test & 10 & 34,50 & $-2,942$ & 9 & ,016 \\
\hline & Post & & 10 & 44,90 & & & \\
\hline \multirow[t]{2}{*}{ M.P.Peran } & Pre & Pair-test & 10 & 35,00 & $-5,029$ & 9 & 001 \\
\hline & Post & & 10 & 43,80 & & & \\
\hline \multirow[t]{2}{*}{ Duametode } & Pre & Pair-test & 20 & 38,50 & $-3,120$ & 19 & ,006 \\
\hline & Post & & 20 & 44,85 & & & \\
\hline \multirow[t]{2}{*}{ Post-Test } & M.Bermain & Independent & 10 & 44,90 & 197 & 18 & 846 \\
\hline & M.P.Peran & & 10 & 43,80 & & & \\
\hline
\end{tabular}

Pada penilaian evaluasi perilaku yang menggunakan skala DS, dapat disimpulkan bahwa perilaku dari seluruh subjek penelitian setelah (post-test) mendapatkan pelatihan DS (rerata 213,40) lebih tinggi secara signifikan $(\mathrm{p}<0,01)$ daripada perila$\mathrm{ku}$ DS dari seluruh subjek penelitian sebelum (pre-test) mendapatkan pelatihan DS (rerata 205,40). Akan tetapi, antara kelompok subjek setelah (post-test) mendapatkan pelatihan dengan metode Bermain dan 
kelompok subjek yang mendapatkan pelatihan dengan metode Permainan Peran tidak didapatkan perbedaan perilaku DS secara signifikan $(p>0,05)$, dengan perilaku DS antara kelompok subjek sebelum (pretest) mendapatkan pelatihan dengan metode Bermain dan kelompok subjek yang mendapatkan pelatihan dengan metode Permainan Peran (lihat Tabel 3).

Apabila dilihat secara lebih rinci lagi pada setiap aspek DS, maka dapat disimpulkan bahwa ada perbedaan secara signifikan $(p<0,05)$ pada kemampuan melakukan Dukungan Penghargaan dan Dukungan Informasional pada kelompok subjek sebelum dan sesudah mendapatkan pelatihan DS, akan tetapi tidak didapatkan adanya perbedaan secara signifikan $(p>0,05)$ kemampuan melakukan Dukungan Emosi, Dukungan Instrumental, dan Dukungan Jaringan Sosial pada kelompok subjek sebelum dan sesudah mendapatkan pelatihan DS (lihat Tabel 4).

Tabel 3

Evaluasi perilaku pelatihan dukungan sosial

\begin{tabular}{lllllccc}
\hline & Komparasi & t-test & $\mathrm{N}$ & Mean & $\mathrm{t}$ & $\mathrm{df}$ & Sig. (2-tailed) \\
\hline Duametode & Pre & Pair-test & 20 & 205,40 & $-2,375$ & 19 &, 028 \\
& Post & & 20 & 213,40 & & & \\
M.Bermain & Pre & Pair-test & 10 & 213,40 &,- 280 & 9 &, 786 \\
& Post & & 10 & 214,40 & & & \\
M.P.Peran & Pre & Pair-test & 10 & 197,40 & $-1,358$ & 9 & \multirow{2}{*}{ 208 } \\
& Post & & 10 & 212,40 & & & \multirow{2}{*}{718} \\
& M.Bermain & Independent & 10 & 221,50 & \multirow{2}{*}{, 367} & \multirow{2}{*}{18} & \\
& M.P.Peran & & 10 & 218,90 & & & \\
\hline
\end{tabular}

Tabel 4

Evaluasi perilaku pada setiap aspek pelatihan DS

\begin{tabular}{llllllc}
\hline \multicolumn{1}{c}{ Aspek } & Komparasi & N & Mean & T & Df & Sig. (2-tailed) \\
\hline D_Emosi & Pre & 20 & 44,20 &, 607 & 19 &, 551 \\
& Post & 20 & 42,75 & & & \\
D_Penghargaan & Pre & 20 & 35,85 & $-3,077$ & 19 &, 006 \\
& Post & 20 & 39,50 & & & \\
D_Instrumental & Pre & 20 & 41,55 & $-1,518$ & 19 &, 145 \\
& Post & 20 & 43,60 & & & \\
D_Informasional & Pre & 20 & 39,15 & $-2,515$ & 19 &, 021 \\
& Post & 20 & 43,55 & & & \\
D_Jaringan_Sos & Pre & 20 & 44,65 &, 426 & 19 &, 675 \\
& Post & 20 & 44,00 & & & \\
\hline
\end{tabular}


Tabel 5

Evaluasi perilaku pada setiap aspek pelatihan DS metode bermain dan metode permainan peran

\begin{tabular}{|c|c|c|c|c|c|c|c|}
\hline Aspek & Metode & Komparasi & $\mathbf{N}$ & Mean & $\mathrm{T}$ & df & Sig. (2-tailed) \\
\hline \multirow[t]{4}{*}{ D_Emosi } & \multirow{2}{*}{ Bermain } & Pre & 10 & 46,90 & \multirow[t]{2}{*}{1,883} & \multirow[t]{2}{*}{9} & \multirow[t]{2}{*}{,092 } \\
\hline & & Post & 10 & 41,30 & & & \\
\hline & \multirow[t]{2}{*}{ P.Peran } & Pre & 10 & 41,50 & \multirow[t]{2}{*}{,- 800} & \multirow[t]{2}{*}{9} & \multirow[t]{2}{*}{,445 } \\
\hline & & Post & 10 & 44,20 & & & \\
\hline \multirow[t]{4}{*}{ D_Penghargaan } & \multirow[t]{2}{*}{ Bermain } & Pre & 10 & 36,20 & \multirow[t]{2}{*}{$-1,550$} & \multirow[t]{2}{*}{9} & \multirow[t]{2}{*}{,156 } \\
\hline & & Post & 10 & 39,40 & & & \\
\hline & \multirow[t]{2}{*}{ P.Peran } & Pre & 10 & 35,50 & \multirow[t]{2}{*}{$-3,209$} & \multirow[t]{2}{*}{9} & \multirow[t]{2}{*}{,011 } \\
\hline & & Post & 10 & 39,60 & & & \\
\hline \multirow[t]{4}{*}{ D_Instrumental } & \multirow[t]{2}{*}{ Bermain } & Pre & 10 & 42,10 & \multirow[t]{2}{*}{$-1,293$} & \multirow[t]{2}{*}{9} & \multirow[t]{2}{*}{,228 } \\
\hline & & Post & 10 & 44,60 & & & \\
\hline & \multirow[t]{2}{*}{ P.Peran } & Pre & 10 & 41,00 & \multirow[t]{2}{*}{,- 809} & \multirow[t]{2}{*}{9} & \multirow[t]{2}{*}{,440 } \\
\hline & & Post & 10 & 42,60 & & & \\
\hline \multirow[t]{4}{*}{ D_Informasional } & \multirow[t]{2}{*}{ Bermain } & Pre & 10 & 36,60 & \multirow[t]{2}{*}{$-2,032$} & \multirow[t]{2}{*}{9} & \multirow[t]{2}{*}{,073 } \\
\hline & & Post & 10 & 43,40 & & & \\
\hline & \multirow[t]{2}{*}{ P.Peran } & Pre & 10 & 41,70 & \multirow[t]{2}{*}{$-3,000$} & \multirow[t]{2}{*}{9} & ,015 \\
\hline & & Post & 10 & 43,70 & & & \\
\hline D_Jaringan_Sos & Bermain & Pre & 10 & 47,20 & 1,142 & 9 & ,283 \\
\hline & & Post & 10 & 45,20 & & & \\
\hline & P.Peran & Pre & 10 & 42,10 &,- 278 & 9 & ,788 \\
\hline & & Post & 10 & 42,80 & & & \\
\hline
\end{tabular}

Tabel 5 menunjukkan apakah ada perbedaan kemampuan melakukan Dukungan Sosial pada setiap aspeknya sebelum dan sesudah mendapatkan pelatihan DS dengan metode Bermain dan metode Permainan Peran. Dari tabel 5 juga dapat ditunjukkan bahwa dari 10 perbedaan yang dapat dipaparkan, hanya ada dua perbedaan yang dapat dinyatakan secara signifikan $(\mathrm{p}<0.05)$ pada kemampuan melakukan Dukungan Penghargaan dan Dukungan Informasional, sebelum subjek mendapatkan pelatihan DS dan setelah subjek mendapatkan pelatihan DS dengan metode Permainan Peran saja. Kemampuan melakukan Dukungan Penghargaan pada kelompok subjek setelah mendapatkan pelatihan DS dengan metode Permainan Peran secara signifikan lebih tinggi daripada kemampuan melakukan Dukungan Penghargaan pada kelompok subjek sebelum mendapatkan pelatihan DS dengan metode Permainan Peran. Demikian juga kemampuan melakukan Dukungan Informasional pada kelompok subjek setelah mendapatkan pelatihan DS dengan metode Permainan Peran secara signifikan lebih tinggi daripada Kemampuan melakukan Dukungan Informasional pada kelompok subjek sebelum mendapatkan pelatihan DS dengan metode Permainan Peran.

\section{Diskusi}

Penelitian ini menyimpulkan bahwa Pelatihan DS dengan menggunakan metode Bermain dan metode Permainan Peran adalah efektif untuk meningkatkan kemampuan walinapi dalam melakukan DS terhadap para narapidana.

Pada pelatihan dukungan sosial ditanamkan aspek-aspek dukungan sosial walinapi yang diturunkan pada setiap sesi 
pelatihan melalui metode bermain peran dan bermain. Pelatihan dukungan sosial di sesi awal dimulai dengan pembukaan yang meliputi ice breaking, penjelasan penelitian dan informed consent kepada peserta pelatihan terlebih dahulu. Selanjutnya diberikan internalisasi aspek-aspek dukungan sosial. Aspek dukungan sosial yang pertama yaitu dukungan emosional mencakup ungkapan empati, kepedulian, dan perhatian terhadap orang yang bersangkutan. Dukungan ini menyediakan rasa nyaman, ketentraman hati, perasaan dicintai bagi seseorang yang mendapatkannya (Sarafino \& Smith, 2014). Tujuantujuan yang dicapai walinapi dalam sesi dukungan emosional menurut Khaerani et al. (2014) yaitu walinapi memiliki empati ikut merasakan apa yang dirasakan orang lain, peserta memiliki kepedulian pada diri sendiri dan orang lain. Aspek yang kedua yaitu dukungan penghargaan. Melalui pembelajaran aspek ini walinapi mampu memberikan penghargaan pada diri sendiri dan orang lain terutama narapidana yang terjadi lewat ungkapan penghargaan positif untuk individu bersangkutan, dorongan maju atau persetujuan dengan gagasan atau perasaan individu dan perbandingan positif individu dengan orang-orang lain (Sarafino \& Smith, 2014). Melalui pembelajaran aspek dukungan penghargaan ini maka walinapi akan dapat memahami dan mampu untuk melakukan ungkapan positif kepada orang lain, mampu memiliki dorongan untuk maju, peserta mampu memberikan penguatan positif (gagasan dan perasaan individu) dan penghargaan kepada orang lain (Khaerani et al., 2014).

Aspek dukungan sosial ketiga yang ditanamkan pada walinapi untuk meningkatkan keterampilan mereka dalam memberikan dukungan sosial yaitu dukungan informasi. Aspek ini mencakup memberi nasihat, petunjuk-petunjuk, saran-saran, informasi, dan umpan balik. Proses pembelajaran pemahaman dan penanaman nilai dukungan informasi menurut Khaerani et al. (2014) yaitu walinapi akan dapat memberikan petunjuk dan saran serta dapat memberikan umpan balik kepada narapidana. Aspek yang keempat yaitu dukungan instrumental yang mencakup bantuan langsung yang dapat berupa jasa, waktu, dan uang (Sarafino \& Smith, 2014). Melalui penanaman aspek ini maka walinapi akan lebih memahami bagaimana dapat membantu narapidana dengan hal yang nyata dan memberi hal yang baik dan berguna (Khaerani et al., 2014). Aspek dukungan sosial yang terakhir yaitu dukungan jaringan sosial. Aspek ini mencakup perasaan keanggotaan dalam kelompok dan saling berbagi kesenangan dan aktivitas sosial (Sarafino \& Smith, 2014). Melalui pelatihan ini walinapi dengan metode bermain dan bermain peran diajak untuk mampu menyampaikan dan mengajak orang lain dalam kegiatan suatu aktivitas sosial. Selain itu walinapi mampu menyatakan dukungannya kepada orang lain untuk melakukan aktivitas sosial (Khaerani et al., 2014).

Di akhir pelatihan ditutup dengan adanya pemaknaan dan refleksi secara menyeluruh terhadap kelima aspek dari dukungan sosial yaitu dukungan emosi, dukungan informasi, dukungan penghargaan, dukungan instrumental dan dukungan jaringan sosial. Pemaknaan ini dilakukan oleh seorang psikolog senior yang memiliki kompetensi dan pemahaman dalam memberikan pelatihan di bidang keterampilan dukungan sosial.

Dari hasil evaluasi reaksi yang didapatkan, bahwa hampir semua subjek peserta pelatihan sepakat bahwa pelatihan DS yang dilaksanakan dinilai menyenangkan, membawa manfaat bagi diri mereka, 
terutama kelompok subjek yang mendapat pelatihan DS dengan metode Permainan Peran merasakan manfaat adanya pemberian informasi baru yang lebih tinggi daripada kelompok subjek yang mendapat pelatihan DS dengan metode Bermain. Hasil evaluasi reaksi ini sesuai dengan pendapat dari Tews \& Noe (In press) yang mengemukakan bahwa lingkungan pelatihan yang menyenangkan meliputi karakteristik pelatih, suasana dan iklim pelatihan serta kesesuaian dengan kebutuhan pelatihan akan menimbulkan pengaruh yang positif pada peserta pelatihan. Tews, Michel, \& Noe (2017) menambahkan berdasarkan hasil penelitiannya menyimpulkan bahwa kegiatan yang menyenangkan dapat menempatkan karyawan dalam situasi baru memungkinkan munculnya kreativitas dan menganalisis masalah dari perspektif yang berbeda pada karyawan.

Pengaruh positif yang memunculkan keterikatan peserta pelatihan untuk berkeinginan belajar dan menghasilkan peningkatan keterampilan dan keterampilan peserta pelatihan (Tews \& Noe, In press). Pernyataan Tews dan Noe ini dikuatkan dengan hasil evaluasi proses belajar atau pengetahuan yang didapatkan pada walinapi yang mengikuti pelatihan bahwa pengetahuan kelompok subjek penelitian sesudah mendapat pelatihan DS lebih tinggi secara signifikan daripada kelompok subjek penelitian sebelum mendapat pelatihan DS. Dalam hal ini tidak didapatkan bukti adanya tingkat pengetahuan yang lebih tinggi pada kelompok subjek pelatihan DS dengan metode Bermain dan kelompok subjek pelatihan DS dengan metode Permainan Peran sesudah pelatihan dibandingkan sebelum pelatihan.

Selain itu hasil evaluasi perilaku didapatkan bahwa kemampuan subjek setelah mendapatkan pelatihan DS (pada dua metode yang dipergunakan) terbukti lebih tinggi daripada kemampuan subjek sebelum mendapatkan pelatihan DS. Metode pelatihan yang menggunakan permainan dan bermain peran mendorong setiap peserta pelatihan untuk dapat berpartisipasi secara aktif sehingga membuat peserta merasa lebih terlibat dan memiliki keinginan untuk mempraktikkan hasil pelatihan. Hasil evaluasi perilaku ini sesuai dengan pendapat dari Bell, Ford, Kraiger, Noe, \& Tannenbaum (2017) yang menjelaskan bahwa desain pelatihan yang mendorong dan mendukung pembelajaran yang lebih aktif pada peserta pelatihan dapat memudahkan pengembangan keterampilan yang lebih kompleks dan sesuai dengan kinerja. Efektivitas metode penyampaian pelatihan tertentu bergantung pada keterampilan dan tugas yang dilatihkan dan hasil belajar yang diinginkan (Bell et al., 2017).

Pada metode pelatihan bermain peran terjadi peningkatan perilaku dukungan sosial walinapi yang lebih tinggi daripada menggunakan metode bermain. Hal ini disebabkan karena dengan metode bermain peran walinapi melakukan proses pembelajaran yang lebih sesuai dan sama seperti saat dalam proses kerja mereka dalam memberikan proses pembinaan kepada narapidana. Proses tersebut sesuai dengan pernyataan bahwa pada metode permainan peran atau drama merupakan proses pengajaran yang tidak hanya mengajarkan pada kognitif dan afektif, akan tetapi juga psikomotorik (Sari, 2017). Sari (2017) menjelaskan bahwa dalam proses role-playing menyediakan contoh hidup dari perilaku manusia secara langsung bagi perserta pembelajaran untuk dapat mengekplorasi perasaan mereka, mendapatkan informasi tentang sikap, nilai-nilai dan persepsi mereka, 
mengembangkan keterampilan dan sikap dalam pemecahan masalah mereka serta dapat mengeksplorasi materi pembelajaran dengan cara yang bervariasi.

Hasil penelitian menguatkan pendapat dari Kolb (2015) yang menyatakan dalam penelitian pada 81 literatur yang meneliti mengenai experiential learning menyatakan bahwa $61,7 \%$ penelitiannya menunjukkan sepakat dengan teori experiential learning yang menyatakan bahwa belajar melalui pengalaman dapat efektif meningkatkan pengetahuan, keterampilan dan merubah perilaku. Pernyataan ini dibuktikan pula dari hasil penelitian dari Bachroni (2011) yang menunjukkan bahwa metode pelatihan pembentukan tim dengan menggunakan metode experiential learning efektif untuk meningkatkan kohesivitas kelompok. Melalui metode experential learning peserta diberikan permainan terlebih dahulu untuk penanaman setiap nilai yang akan diberikan dan diajak untuk mencari makna apa yang dapat didapatkan serta mengajarkan bagaimana penerapannya dalam dunia kerja.

Dari penelitian ini dapat disimpulkan bahwa walaupun terdapat perbedaan secara signifikan pada evaluasi pengetahuan, namun pada evaluasi reaksi dan evaluasi perilaku tidak didapat perbedaan secara signifikan antara pelatihan DS menggunakan metode Bermain dengan pelatihan DS menggunakan metode Permainan Peran.

Di sisi lain peneliti melihat adanya beberapa keterbatasan penelitian dalam proses penelitian ini yang harapannya akan bisa diperbaiki dan disempurnakan pada penelitian di masa depan. Pemberian kueisoner langsung kepada walinapi untuk mengukur perubahan perilaku pemberian dukungan sosial kepada walinapi masih memunculkan bias dalam jawaban yang diberikan oleh mereka. Diperlukan metode dan responden pengukuran tambahan yang lebih obyektif untuk melihat adanya perubahan kemampuan mereka dalam memberikan dukungan sosial kepada narapidana selama proses pembinaan. Selain itu pemberian waktu pelatihan dukungan sosial yang pendek kepada peneliti oleh Lembaga Pemasyarakatan diharapkan dapat lebih ditingkatkan untuk dapat lebih memaksimalkan proses pembelajaran dalam pemberian keterampilan dukungan sosial.

\section{Kesimpulan}

Dari hasil penelitian yang dilakukan dapat disimpulkan bahwa: (1) pelatihan Dukungan Sosial adalah efektif dalam meningkatkan kemampuan melakukan dukungan sosial walinapi terhadap narapidana; (2) tidak ada perbedaan efektivitas secara signifikan antara pelatihan dukungan sosial yang menggunakan metode Bermain (game) dan Permaian Peran (role play).

\section{Saran}

Kepada Lembaga Pemasyarakatan Kelas II. A Wirogunan diharapkan dapat melakukan pelatihan Dukungan Sosial ini kepada seluruh walinapi karena terbukti dapat meningkatkan kemampuan walinapi dalam melakukan dukungan sosialnya terhadap narapidana. Walaupun secara keseluruhan tidak terbukti adanya perbedaan efektivitas antara metode Bermain dan Permainan Peran, tetapi pelatihan DS dengan menggunakan Permainan Peran dapat lebih ditekankan karena (1) terbukti penilaian peserta merasa mendapat informasi lebih, (2) terbukti dapat lebih melakukan kemampuan Dukungan Penghargaan dan Dukungan Informasi, daripada pelatihan DS dengan menggunakan metode Bermain. 


\section{Kepustakaan}

Alkin, M. C. (2012). Evaluation roots: A wider perspective of theorist' views and influences. Los Angeles: Sage Publications Inc.

Ancok, D. (2002). Outbound management training: Aplikasi ilmu perilaku dalam pengembangan sumber daya manusia. Yogyakarta: Universitas Islam Indonesia.

Bachroni, M. (2011). Pelatihan pembentukan tim untuk meningkatkan kohesivitas tim pada Kopertis V Yogyakarta, Jurnal Psikologi, 38(1), 4051. doi: 10.22146/jpsi.7663

Bell, B. S., Ford, K. J., Kraiger, K., Noe, R. A., \& Tannenbaum, S. I. (2017). 100 years of training and development research: What we know and where we should go. Journal of Applied Psychology, 102(3), 305-323. doi: 10.1037/ap10000142

Betcherman, G. (1998). Training for the new economy a synthesis report. Ottawa: Renouf Publishing Co.Ltd.

Cole, G. A. (2002). Personnel and human resource management (Fifth edit). London: Thomson Learning. Retrieved from https://books.google.co.id/ books ?id=Lrpmdm5ShUkC

Cook, T. D. (2014). Generalizing causal knowledge in the policy sciences: External validity as a task of both multiattribute representation and multiattribute extrapolation. Journal of Policy Analysis and Management, 33(2), 527-536. doi: 10.1002/pam. 21750

Hupcey, J. E. (1998). Clarifying the social support theory - research linkage. Journal of Advanced Nursing, 27(6), 1231-1241.

Johnson-Laired, P. N., \& Johnson-Laird, P. N. (1999). Deductive reasoning. Annual Review of Psychology, 50, 109-135. doi: 10.1146/annurev.psych.50.1.109

Johnson, D. W., \& Johnson, F. P. (2013). Joining together: Group theory and group skills. London: Pearson Education Limited. doi: 10.1037/014685

Khaerani, N. M., Palila, S., Islam, U., Sunan, N., \& Yogyakarta, K. (2014). Pelatihan dukungan sosial untuk meningkatkan optimisme dan kemandirian penyintas lahar dingin merapi yogyakarta. Jurnal Intervensi Psikologi, 6, 34-49.

Kirkpatrick, J. D., \& Kirkpatrick, W. K. (2016). Kirkpatrick's four levels of training evaluation. USA: ATD Press.

Kolb, D. A. (2015). Experiential learning: Experience as the source of learning and development. USA: Pearson Education Inc.

Kunche, A., Kumar Puli, R., Guniganti, S., \& Puli NIT Warangal Andhra Pradesh, D. (2011). Analysis and evaluation of training effectiveness. Human Resource Management Research, 1(1), 1-7. doi: 10.5923/ j.hrmr.20110101.01

Mathis, R. L., Jackson, J. H., Valentine, S. R., \& Meglich, P. (2015). Human resource management, fifteenth edition. USA: Cengage Learning. Retrieved from https://books.google.co.id/ books?id=ihBCgAAQBAJ

Pareek, U. N., Venkateswara Rao, T., \& Khandelwal, A. K. (2016). HRD, OD, and institution building: Essays in memory of Udai Pareek. New Delhi: Sage Publications Inc.

Raheja, K. (2015). Methods of training and development. Innovative Journal of Business and Management, 3(2), 35-41.

Riggio, R. E. (2015). Introduction to industrial and organizational psychology. New York: Routledge, Taylor and Francis Group.

Robbins, S. (2008). Perilaku organisasi 1 (ed. 
12) HVS. Jakarta: Salemba Empat.

Sahrah, A., Yuniasanti, R. I., \& Indiyah. (2015). Correlation of social support custodian to subjective well being prisoners at Penitentiary Class II.A Yogyakarta. Proceeding. International Seminar 2015, Universitas Mercu Buana Yogyakarta. Diunduh dari http://lppm.mercubuana-yogya.ac.id /wp- content/uploads/2017 /04/ Alimatus -Sahrah_UMBY3.pdf

Sahrah, A; Lailatushifah, S. N. F; Indiyah; Susilaningsih, K. T. \& Astuti, A. (2014). Structural model of the influencing factors of the subjective well-being of the prisoners. Jurnal ilmiah Psikologi Industri dan Organisasi, 1(1), 1-13.

Sarafino, E. P., \& Smith, T. W. (2014). Health psychology biopsychosocial interactions. Journal of Psychosomatic Research. doi: 10.1016/0022-3999(91) 90058-V
Sari, S. P. N. (2017). Penggunaan Metode Bermain Peran (Role Playing) untuk Meningkatkan Ketrampilan dan Sikap Bekerja Sama dalam Bermain Drama Pada Siswa Kelas VIII B SMP Institue Indonesia Yogyakarta Tahun Ajaran 2015/2016.

Sugiyono. (2010). Metode penelitian kuantitatif, kualitatif, RED. Bandung: Alfabet.

Tews, M. J., Michel, J. W., \& Noe, R. A. (2017). Does fun promote learning? The relationship between fun in the workplace and informal learning. Journal of Vocational Behavior, 98, 46-55. doi: 10. 1016/j.jvb.2016.09.006

Tews, M. J., \& Noe, R. A. (Accepted/In press). Does training have to be fun? A review and conceptual model of the role of fun in workplace training. Human Resource Management Review. doi: 10.1016/ j.hrmr.2017.11.003

Peneliti mengucapkan terima kasih kepada Direktorat Perguruan Tinggi Republik Indonesia, Kopertis Wilayah V Daerah Istimewa Yogyakarta, Ka LPPM dan Dekan Fakultas Psikologi Universitas Mercu Buana Yogyakarta, yang telah memberikan kesempatan dan pendanaan di tahun 2016 untuk penelitian ini. Kami ucapkan terima kasih pula kepada Kepala Lapas II Wirogunan Yogyakarta yang telah memberikan izin untuk melaksanakan penelitian di Lapas Kelas II.A Wirogunan Yogyakarta. 